
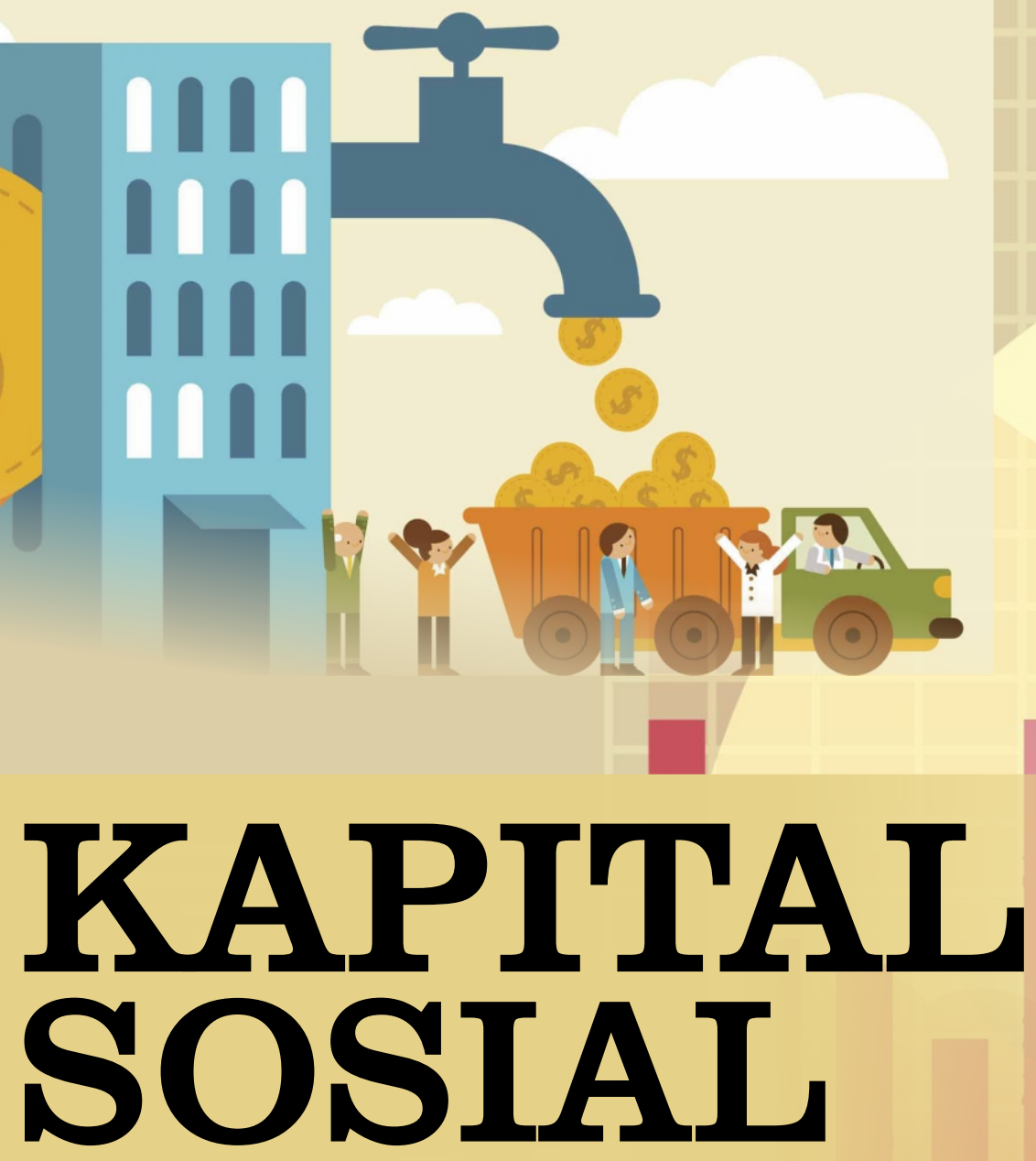

(Sebuah Kekuatan Dalam Kehidupan NKRI)
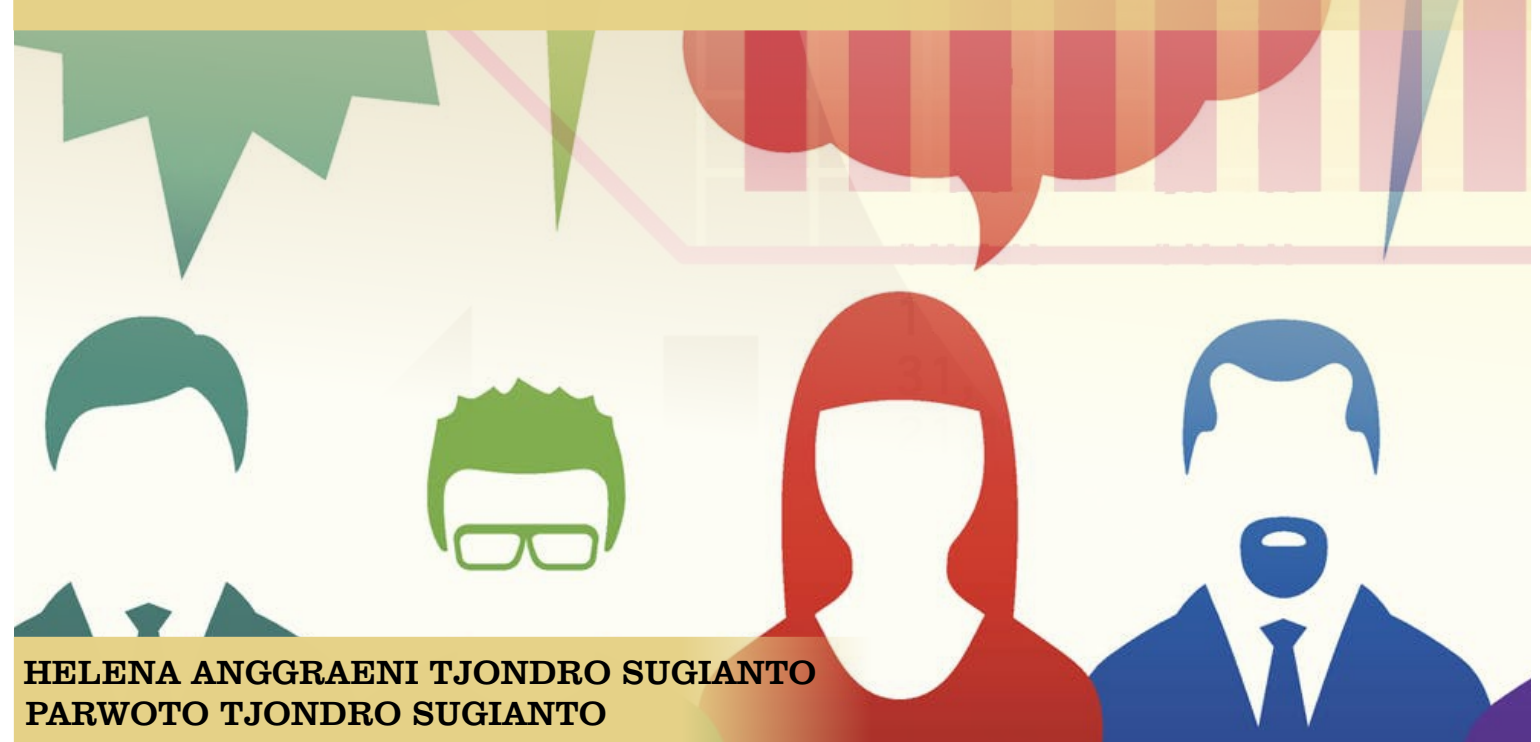


\title{
KAPITAL SOSIAL
} "SEBUAH KEKUATAN DALAM HIDUP NKRI"

\author{
PENULIS \\ Helena Anggraeni Tjondro Sugianto \\ Parwoto Tjondro Sugianto
}

\section{PENERBIT \\ TOHAR MEDIA}


KAPITAL SOSIAL

"Sebuah Kekuatan Dalam HIdup NKRI"

Penulis : Helena Anggraeni Tjondro Sugianto, Parwoto Tjondro Sugianto

ISBN : 978-623-7485-33-9

Desain Sampul dan Tata Letak

Ai Siti KHairunisa

Penerbit

CV. Tohar Media

Anggota IKAPI No. 022/SSL/2019

\section{Redaksi :}

JL. Rappocini Raya Lr 11 No 13 Makassar

JL. Hamzah dg. Tompo. Perumahan Nayla Regency Blok D No.25 Gowa

Telp. (0411) 8987659/0852-4353-7215

Email : toharmedia@yahoo.com

Website : https://toharmedia.co.id

Cetakan Pertama Mei 2020

Hak Cipta dilindungi undang-undang.

Dilarang memperbanyak sebagian atau seluruh isi buku ini dalam bentuk apapun, baik secara elektronik maupun mekanik termasuk memfotocopy, merekam atau dengan menggunakan sistem penyimpanan lainnya, tanpa izin tertulis dari penerbit.

Undang-undang Nomor 19 Tahun 2002 Tentang Hak Cipta

1. Barang siapa dengan sengaja dan tanpa hak mengumumkan atau memperbanyak suatu ciptaan atau memberi izin untuk itu, dipidana dengan pidana penjara paling lama 7 (Tujuh) tahun dan/atau denda paling banyak Rp. 5.000.000.000,00 (Lima Miliar Rupiah)

2. Barang siapa dengan sengaja menyiarkan, memamerkan, mengedarkan, atau menjual kepada umum suatu ciptaan atau barang hasil pelanggaran hak cipta atau hak terkait sebagaimana dimaksud pada ayat 1 , dipidana paling lama 5 (lima tahun) dan/atau denda paling banyak Rp. 500.000.000,00 (Lima Ratus Juta Rupiah 


\section{KATA PENGANTAR}

Syukur kepada Allah bahwa akhirnya buku ini dapat terselesaikan pada waktunya. Buku ini ditulis untuk membuka wawasan mengenai Kapital Sosial, sebuah modal yang seringkali tak dilirik namun sebetulnya sangat potensial dan sudah tertanam di banyak kelompok jaringan masyarakat. Dalam rangka mempertahankan NKRI tetap lestari dan di tengah situasi sumber daya alam yang semakin menipis serta finansial yang kembang kempis, kapital sosial menjadi isu menarik yang berpotensi untuk menjadi solusi.

Kapital Sosial lahir karena adanya rasa percaya atau lazim disebut trust di kalangan sekelompok masyarakat yang diikat oleh norma hidup bersama. Kondisi inilah yang membentuk kelompok masyarakat tersebut menjadi sebuah jaringan yang dapat berpotensi menjadi kapital sosial. Untuk dapat memperkuat ketahanan NKRI sekaligus meningkatkan kesejahteraan bersama, dibutuhkan sebuah jaringan sosial yang kuat, yang tidak mudah digoyahkan oleh isu-isu miring sehingga pembangunan dapat terus berjalan dengan lancar.

Kapital Sosial ini dapat menjadi fondasi efektif untuk meningkatkan ketahanan sosial dan bahkan sekaligus ketahanan ekonomi, karena jaringan kelompok masyarakat yang padu dapat menjadi sebuah kekuatan sosial yang dapat mendatangkan keuntungan secara ekonomi dan sosial sehingga membuahkan peningkatan kesejahteraan bersama. Demikianlah buku ini disusun, kiranya dapat berbuah dengan baik dan memberikan manfaatnya sesuai dengan harapan. 


\title{
DAFTAR ISI
}

\author{
Halaman Sampul \\ Halaman Penerbit ${ }^{-}$ii \\ Kata Pengantar _iii \\ Daftar Isi iv
}

\section{Bab 1. Kapital Sosial Dalam Konsep _ 1}
A. Latar Belakang _ 1
B. Pengertian Kapital Sosial 7
C. Unsur-Unsur Kapital Sosial_ 9

\section{Bab 2. Tipologi Kapital Sosial_ 13}
A. Sumber Utama Kapital Sosial__13
B. Tipologi Kapital Sosial _ 15

Bab 3. Kapital Sosial Dibalik Budaya Masyarakat _19
A. Kapital Sosial Dalam Kultural _ 19
B. Potret Kapital Sosial di Berbagai Negara 22
C. Kapital Sosial dan Etnis Dalam Pembangunan Ekonomi 27

Bab 4. Pembangunan Manusia 31
A. Peran Kapital Sosial Dalam Pembangunan Manusia _31
B. Kapital Sosial dan Pembangunan Manusia Dalam
Komunitas Masyarakat _32
C. Lembaga-Lembaga Formal _ 36

Bab 5. Kapital Sosial Dalam Manajemen Bisnis _ 39
A. Kapital Sosial Dalam Dunia Manajemen 39
B. Kapital Sosial Dalam Bisnis _ 42

Bab 6. Kapital Sosial Dalam Civil Society _ 45
A. Revolusi Kapital Sosial dan Civil Society _ 45
B. Manfaat Kapital Sosial Dalam Kehidupan Bermasyarakat _49
C. Penutup _50

Daftar Pustaka_53 
KAPITAL SOSIAL "SEBUAH KEKUATAN DALAM HIDUP NKRI" 



\section{BAB 1 \\ KAPITAL SOSIAL DALAM KONSEP}

\section{A. Latar Belakang}

Negara Kesatuan Republik Indonesia dibangun oleh para bapak bangsa melalui perjalanan dan sejarah yang panjang. Dalam tigaperempat abad NKRI dengan dasar Pancasila telah mengayomi ratusan juta rakyatnya. Namun, tak dipungkiri sejarah mencatat adanya upaya upaya untuk mengguncang NKRI dalam perjalanan Indonesia sebagai sebuah bangsa yang besar. Kebhinekaan seringkali tidak lagi tunggal ika tetapi menjadi sumber perpecahan yang bermuara kepada upaya untuk menggoyang NKRI. Oleh karenanya, berbagai potensi yang dapat dioptimalkan untuk dapat mempertahankan NKRI perlu digali dan dikembangkan.

Kapital sosial merupakan sebuah modal yang sudah ada di tengah masyarakat, dan berpotensi besar untuk meningkatkan ketahanan nasional. Selama ini kapital sosial seringkali dikaitkan dengan ekonomi namun tentunya dapat juga dimanfaatkan untuk peningkatan kesejahteraan bersama melalui ketenteraman dan keamanan negara. Fakta menunjukkan 
BAB 1 : Kapital Sosial Dalam Konsep negara-negara yang maju dan aman adalah negara yang penduduknya bahagia serta memiliki rasa percaya yang tinggi baik terhadap sesama masyarakat maupun terhadap pemerintah.

Beberapa dekade terakhir Indonesia seringkali digolongkan sebagai "negara berkembang" yang dengan perkataan lain menyatakan tidak termasuk kategori "negara maju." Setelah lebih dari 70 tahun Indonesia merdeka, rupanya Indonesia masih juga belum bisa menembus lapisan jajaran elite negara-negara maju. Sementara negara-negara lain di Asia yang lebih kecil ataupun yang lebih hancur kondisinya akibat perang dunia dengan segera menempatkan diri sebagai negara maju, misalnya Singapura, Jepang, Korea Selatan, dan lain-lain. Masa pemerintahan Republik Indonesia saat ini memang membawa angin segar yang memberikan harapan baru. Namun, tak dapat disangkal bahwa masih banyak pekerjaan rumah yang harus digarap bersama oleh Indonesia sebagai sebuah bangsa untuk dapat menjadi negara yang maju. Indonesia sesungguhnya memiliki kekayaan alam yang luar biasa dan kawasan yang sangat luas terbentang 60 04'30" Lintang Utara sampai 11000 ' 36" Lintang Selatan dan antara 940 58' 21' sampai 1410 01' 10' Bujur Timur.

Samudera luas membentang dari barat hingga ke timur, sungaisungai besar yang mengalir dengan banyak ikan di dalamnya, hutan yang 
lebat dengan kekayaan flora dan faunanya, semua itu ada di Indonesia. Akan tetapi, sejarah memotret bahwa itu semua tinggal sejarah belaka di banyak tempat. Sungai yang jernih dan dalam menjadi keruh dan dangkal, hutan yang lebat dan hijau menjadi semak dan bahkan menjadi hutan asap, yang jika dibiarkan terus menerus semua kekayaan Indonesia itu hanya akan menjadi sekedar cerita bagi generasi yang akan datang. Dalam hal ini telah terjadi kegagalan besar dalam sudut pandang pembangunan yang berkelanjutan. Hutan-hutan dikonversi menjadi perkebunan tanpa evaluasi dan analisis lingkungan yang mendalam lebih dahulu, sungai-sungai menjadi keruh karena ditambang tanpa prosedur, ilegal logging marak dilakukan selama beberapa dasawarsa di berbagai tempat, semua itu menjadikan kekayaan bumi Indonesia tidak lagi lestari. Kesalahan manajemen yang dilatarbelakangi keserakahanan bisnis memang membangkitkan ekonomi dalam sekejap namun dengan segera pula menjerumuskannya ke titik nadir ekonomi untuk waktu yang panjang. Kondisi seperti ini akan memudahkan penyulutan yang mengkambinghitamkan kebhinekaan, yang padahal, tak ada hubungannya dengan kemiskinan.

Apa yang kemudian terjadi? Di beberapa tempat didapati tanah yang tandus, sungai yang kering, bangunan SD yang ambruk, jalan tanah 
BAB 1 : Kapital Sosial Dalam Konsep

yang tak kunjung diaspal, listrik yang belum masuk, dan untuk semua ini yang selalu dijadikan alasan adalah karena tidak adanya dana yang mencukupi. Perekonomian rakyat memang semakin melemah seiring dengan merosotnya kekayaan bumi yang bisa digarap. Wirausaha pun tidak lagi berjalan karena tidak ada yang dapat diperjualbelikan.

Namun, benarkah demikian? Itu benar adanya jika modal yang dimiliki hanya modal finansial semata. Akan tetapi, sebetulnya ada banyak modal lain yang belum digali atau digunakan semaksimal mungkin. Walau tidak ada dana, tapi dengan bergotong royong bangunan SD yang ambruk bisa terbangun kembali, jalan yang berlubang bisa mulus kembali, dan banyak hal bisa dilakukan dan dibangun jika terjadi kerjasama. Inilah yang dimaksud dengan kapital sosial. Perpecahan dan saling mencurigai juga dapat diatasi jika di tengah masyarakat ada kapital sosial yang kuat.

Kapital Sosial atau yang biasa juga disebut sebagai Modal sosial merupakan sebuah modal yang sudah ada dan tertanam di kalangan masyarakat. Seringkali orang berpikir modal berkaitan erat dengan finansial, padahal masih banyak modal lain yang jika dikembangkan dapat mendatangkan keuntungan. Dalam diri manusia sendiri terdapat banyak hal yang bisa menjadi modal untuk mengembangkan sebuah usaha, misalnya kepandaian, kepribadian, keterampilan, dan sebagainya yang 
berpadu menjadi sebuah modal yang besar dan penting. Modal ini disebut sebagai Human Capital atau modal manusiawi. Selain itu alam semesta yang kaya raya juga menjadi modal yang besar untuk mendongkrak perekonomian masyarakat sehingga disebut sebagai sumber daya alam. Demikianlah pada kenyataannya begitu banyak modal yang ada sehingga untuk mengembangkan sebuah usaha, manusia tidak dapat bergantung kepada modal finansial semata. Di lain pihak, tidak mempunyai uang bukan berarti tidak mempunyai modal karena ternyata masih banyak modal lain yang bisa dikembangkan. Jika dipetakan, modal finansial atau uang hanyalah satu dari sekian banyak modal yang ada. Berikut ini digambarkan beberapa di antara sekian banyak modal yang dikenal dalam dunia ekonomi.
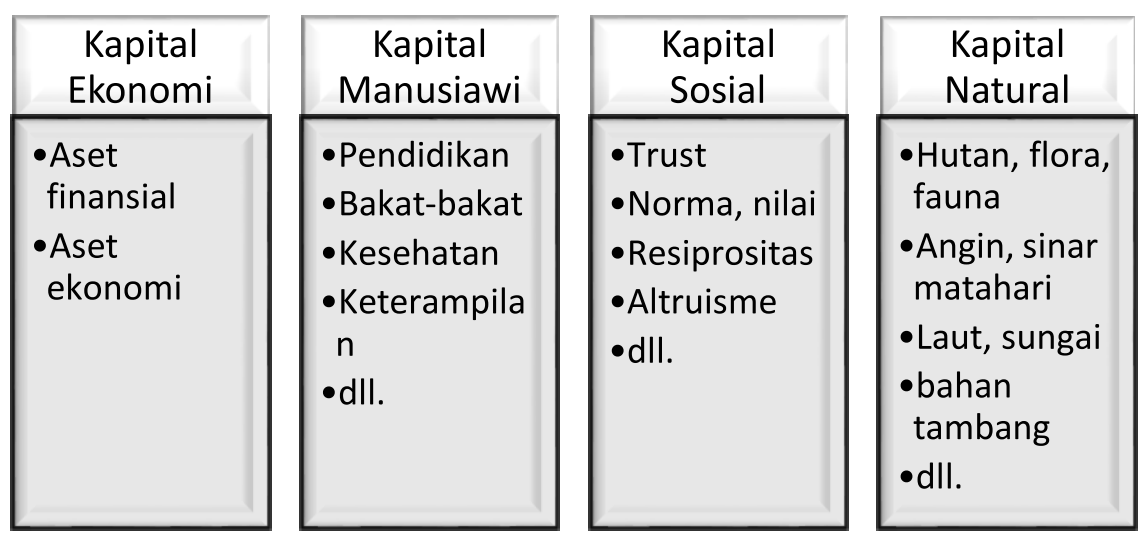

Gambar 1 Berbagai modal dalam dunia ekonomi 
Pendalaman mengenai kapital sosial ini semakin perlu dikembangkan mengingat situasi tanah air yang sumber daya alamnya semakin terbatas dan sejarah yang mencatat adanya upaya-upaya untuk menggoyang NKRI. Kenyataannya, cukup banyak negara di dunia ini yang sumber daya alamnya sangat terbatas telah menjadi negara maju yang

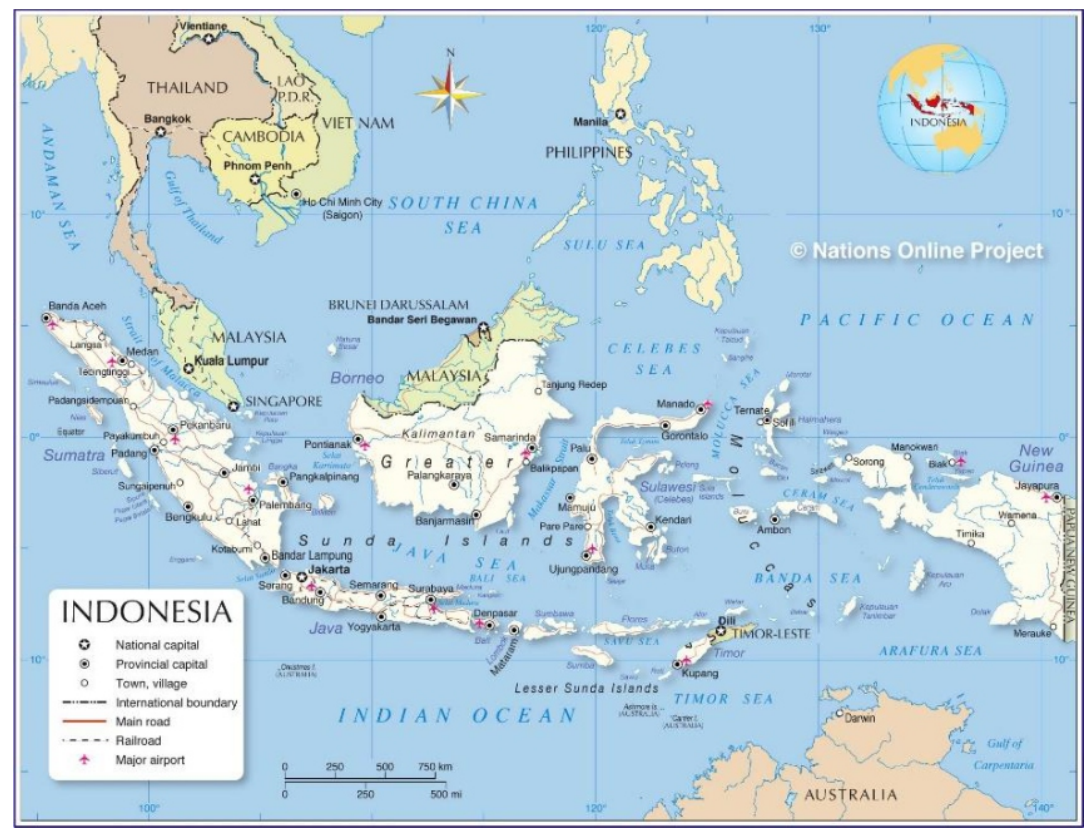

Gambar 2 Peta Indonesia

memberikan kesejahteraan kepada masyarakatnya baik secara finansial maupun rasa aman. Seluruh kenyataan ini mendorong manusia untuk memikirkan modal lain yang tidak bersifat material atau ekonomi. Dalam hal ini, kapital sosial dapat menjadi solusi atas segala permasalahan sehubungan dengan kondisi tanah air yang digambarkan di atas. 


\section{B. Pengertian Kapital Sosial}

Kamus Besar Bahasa Indonesia ${ }^{1}$ menjelaskan modal adalah uang yang dipakai sebagai pokok (induk) untuk berdagang, melepas uang, dan sebagainya; atau modal adalah harta benda (uang, barang, dan sebagainya) yang dapat dipergunakan untuk menghasilkan sesuatu yang menambah kekayaan. Dijelaskan pula bahwa modal merupakan barang yang digunakan sebagai dasar atau bekal untuk bekerja (berjuang, dan sebagainya). Dapatlah dimengerti sekarang bahwa modal merupakan sesuatu yang dapat mendatangkan keuntungan. Akan tetapi, ketika modal yang bersifat material seperti uang atau barang terbatas, perlu dilirik modal lain yang sebetulnya sudah ada di dalam diri setiap orang atau tertanam di kalangan masyarakat. Dalam hal inilah kapital sosial perlu dipelajari karena walaupun tidak bersifat material tetap memiliki sifat sebagai modal yang dapat mendatangkan keuntungan.

Definisi kapital sosial atau modal sosial sangat variatif. Banyak penelitian memberikan definisinya secara berbeda-beda sesuai dengan hasil penelitiannya. Para ilmuwan baik di bidang ekonomi, sosiologi, maupun politik, memberikan pengertian tersendiri sesuai dengan hasil

\footnotetext{
${ }^{1}$ Kamus Besar Bahasa Indonesia $\mathrm{V}$
} 
BAB 1 : Kapital Sosial Dalam Konsep

temuannya di lapangan. Walaupun demikian, Fukuyama (2012) mengatakan bahwa semua sepakat bahwa jaringan sosial dapat memengaruhi perekonomian, dan hal terpenting yang perlu ada dalam jaringan sosial itu tidak lain adalah rasa percaya atau trust. Dengan demikian, kapital sosial dapat dimengerti sebagai totalitas norma, relasi sosial, dan jaringan sosial yang mengembangkan perilaku kooperatif di kalangan masyarakat. Dengan kata lain kapital sosial dapat didefinisikan sebagai segala perilaku baik yang membuat masyarakat bersekutu untuk mencapai satu tujuan atas dasar kebersamaan, yang di dalamnya diikat oleh nilai dan norma yang dipatuhi bersama pula.

Coleman (2009), mendefinisikan Kapital Sosial sebagai varian entitas, terdiri dari beberapa struktur sosial yang memfasilitasi tindakan dari para pelakunya yang menciptakan berbagai ragam kewajiban sosial, menciptakan iklim saling percaya, membawa saluran informasi dan menetapkan norma-norma dan sanksi sosial bagi para anggotanya. Kesimpulannya kapital sosial merupakan sekumpulan norma informal yang dapat menjalin para anggotanya dalam sebuah kerja sama sehingga dapat mereduksi biaya transaksi (Fukuyama, 2012). Kapital sosial terbentuk melalui pola-pola interaksi sosial yang terjadi di dalam sebuah kelompok masyarakat yang saling bergantung satu sama lain (La Due Lake 
\& Huckfeldt, 1998). Sumber dari kapital sosial selalu dari sekelompok individu yang menerapkan perilaku baik dan saling berinteraksi satu sama lain (Villalonga-Olives \& Kawachi, 2015).

\section{Unsur-unsur Kapital Sosial}

Kapital sosial senantiasa berkaitan dengan nilai atau norma (value), jaringan sosial atau relasi (networking), dan rasa percaya (trust) (Putnam, 1995). Norma yang dihidupi oleh sekelompok masyarakat dapat menghasilkan rasa percaya di antara mereka, karena mereka hidup dengan diikat oleh norma dan nilai-nilai yang sama. Misalnya, sesama orang Jepang saling mempercayai satu sama lain karena mereka percaya bahwa mereka semua adalah satu keluarga dengan Kaisar sebagai kepala keluarganya. Inilah norma yang ada di antara mereka sehingga nilai-nilai saling menghargai dan percaya sangat kuat tumbuh di kalangan mereka (Bellah, 2009). Jadi dapat dikatakan bahwa unsur utama kapital sosial adalah rasa percaya (trust), nilai atau norma, dan jaringan sosial 


\section{UNSUR UTAMA KAPITAL SOSIAL}

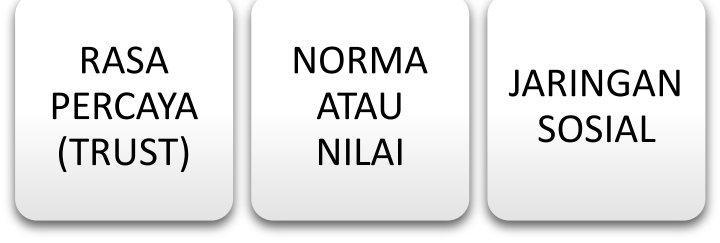

Gambar 3 Unsur utama kapital sosial

Selain ketiga unsur utama di atas, dalam Kapital Sosial juga ditemukan unsur-unsur lain juga yang dipandang sangat penting yang memicu terbangunnya unsur unsur utama tadi, yaitu resiprositas, nilai-nilai budaya yang dihidupi bersama, dan partisipasi.
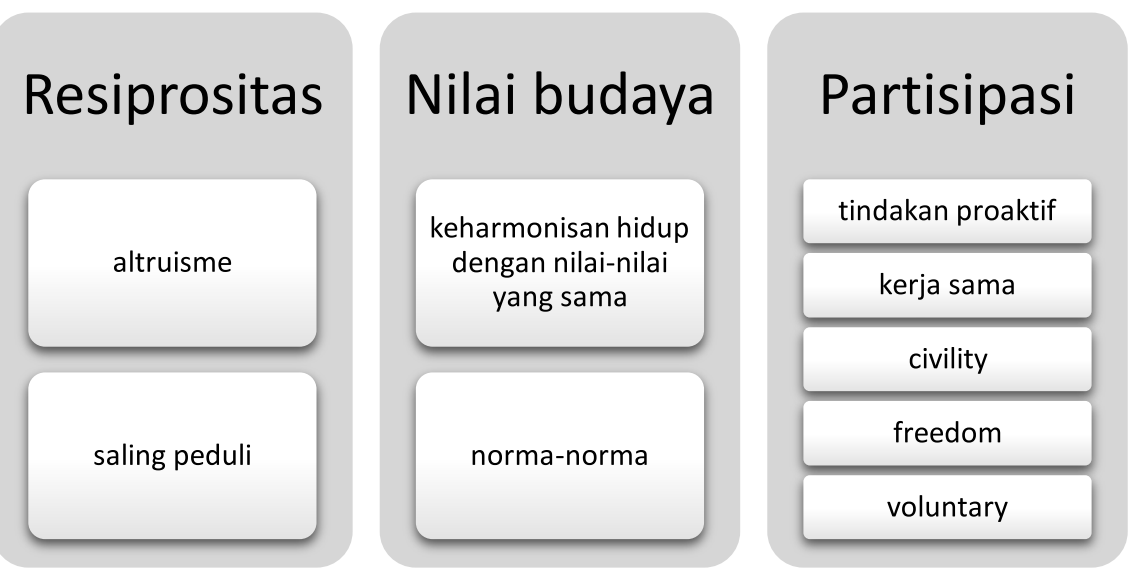

Gambar 4 Unsur tambahan dalam Kapital Sosial 
Dalam sebuah entitas sosial adanya unsur resiprositas dapat membangun sebuah kapital sosial yang kuat. Unsur resiprositas ini terbentuk ketika ada altruisme antar anggota masyarakat, sikap saling peduli satu sama lain, ringan tangan untuk menolong sesama, dan terdapat rasa empati yang besar. Resiprositas ini sangat berbeda dengan sekedar memberi dan menerima sebab resiprositas ini dasarnya adalah altruisme, yaitu ketika terjadi saling perduli dan mengutamakan kepentingan orang lain. Artinya kalau tiap orang memperoleh sesuatu, itu karena tiap orang saling memberi, saling mengasihi, saling menopang. Sementara memberi dan menerima dasarnya adalah untung rugi jadi. Perilaku resiprositas tersebut kalau sering dilakukan akan menjadi kebiasaan/habit yang kalau terus dilakukan maka akan terbentuk budaya hidup.

Oleh sebab itu budaya hidup juga dapat mengambil bagian penting dalam membangun sebuah kapital sosial. Nilai-nilai dan norma-norma yang lahir dari kebiasaan resiprositas akan tertanam dalam kehidupan bersama membentuk sebuah budaya hidup yang menciptakan keharmonisan. Kapital sosial tumbuh dan menjadi kuat di tengah komunitas yang hidup harmonis.

Hal penting lainnya yang juga menjadi unsur terbentuknya sebuah kapital sosial adalah partisipasi. Masyarakat yang tingkat partisipasinya 
tinggi memiliki ciri-ciri civility, yaitu setiap anggota merasa dirinya merupakan bagian dari warga keseluruhan. Hal itu mendorong mereka untuk bersikap proaktif dan dapat bekerja sama dengan baik. Selain itu, rasa percaya atau trust satu sama lain membuat mereka memiliki freedom, yaitu berani untuk secara merdeka berpendapat, dan menghayati nilai-nilai equality atau kesetaraan dan voluntary atau kerelaan untuk berkontribusi demi kepentingan umum. 


\section{BAB 2 TIPOLOGI KAPITAL SOSIAL}

\section{A. Sumber Utama Kapital Sosial}

Fukuyama (2012) mengatakan bahwa sumber utama dari kapital sosial adalah agama, tradisi, dan lembaga pendidikan. Dikatakannya demikian karena di ketiga sumber utama tersebut berkembang nilai-nilai atau norma yang dihidupi bersama sehingga muncul trust yang besar antara yang satu dengan lainnya dalam sebuah kelompok jaringan masyarakat.

Norma sosial merupakan serangkaian aturan tidak tertulis yang dihidupi bersama oleh sekelompok masyarakat. Sementara yang dimaksud dengan nilai adalah suatu kebenaran yang diwarisi turun temurun oleh sekelompok masyarakat. Nilai-nilai inilah yang menjadi latar belakang dari berbagai aturan maupun kebijakan yang berkembang di kalangan masyarakat yang bersangkutan. Itulah sebabnya tak mengherankan jika dalam suatu kelompok masyarakat yang hidup dalam norma dan nilai-nilai yang sama akan muncul rasa percaya atau trust satu sama lain. Trust ini merupakan hubungan antara dua orang atau lebih yang dilandasi rasa 